\title{
How do Indonesian Children View Humorous Advertising on YouTube?
}

\author{
Sri Rahayu ${ }^{1}$, Naldo $^{1}$, Hardika Widi Satria ${ }^{1}$ \\ ${ }^{1}$ Social and Humanities Department, Communication-Advertising Studies, \\ Vocational Education Program, Universitas Indonesia \\ *Email: sri@ vokasi.ui.ac.id
}

\begin{abstract}
This article explores Indonesian children's views about humorous advertising on YouTube in the light of advertising effectiveness. The participants were 840 children aged 7 to 12 years, who were students at both public and private elementary schools. The study was carried out in a natural setting. The children watched a short movie with humorous advertising videos before and after. Next, a survey assessed their perceptions of the advertisements and the advertising effectiveness using essential indicators such as attitude toward the ad and attitude toward the brand. The data were analyzed with simple regression and analysis of variance (ANOVA). This study contributes to research on humorous advertising by introducing the perspectives of Indonesian children. It offers valuable input for those interested in commercials, both academics and practitioners, especially those who work in the Indonesian context.
\end{abstract}

Keywords: YouTube advertising, humorous advertising, Indonesian children, children's perceptions of humorous advertising

\section{Introduction}

In the 1970s, advertising research focused largely on attitude toward the brand. It was not until the 1980s that some literature argued this approach was too rational. Instead, it was suggested to concentrate on two postulates: a specific reaction to the advertising and how this particular response influences consumers' attitude toward the brand (Derbaix \& Bree, 1997). Therefore, research has to be more specific about what kind attitude is being explored.

Currently, attempts at using humor in global advertising campaigns are on the rise. However, the appeal of humor in advertising is that it creates more of an instinct rather than evidence (Crawford \& Gregory, 2015). Research is needed to clarify the topic of humorous advertising, such the effects and effectiveness of humor in cross-cultural advertising settings, the nature of humor used in advertising, typologies that extend across cultural borders, and measures of responses to humorous advertising, not to mention how audience responses to humor depend on an array of factors including demographics, psychographics, culture, and behavioral variables (e.g., brand familiarity) (Crawford \& Gregory, 2015). As an attempt to fill in this gap, this article explores Indonesian children's views about humorous advertising in the light of advertising effectiveness.

Advertisers agree that children are a lucrative market to be tapped Linn, 2004. Most U.S. advertising agencies spend an estimated $\$ 10$ billion per year on television advertising to children, since in 2002, children aged 4-12 years spent $\$ 30$ billion of their own money and influenced up to $\$ 600$ billion of household expenditures Schor \& Ford, 2007. However, the world is now shifting into the digital era. Children are watching TV less and using the Internet more, especially in Indonesia. The Internet penetration of Indonesia has reach 51 percent from the average global rate with ten percent year-on-year growth (WeAre, 2017). Not to mention hours spent for digital media that is outnumbers the traditional media. Most Indonesian spends an average six to seven hours per day using digital media, mostly for social networking (Fig. 1). 


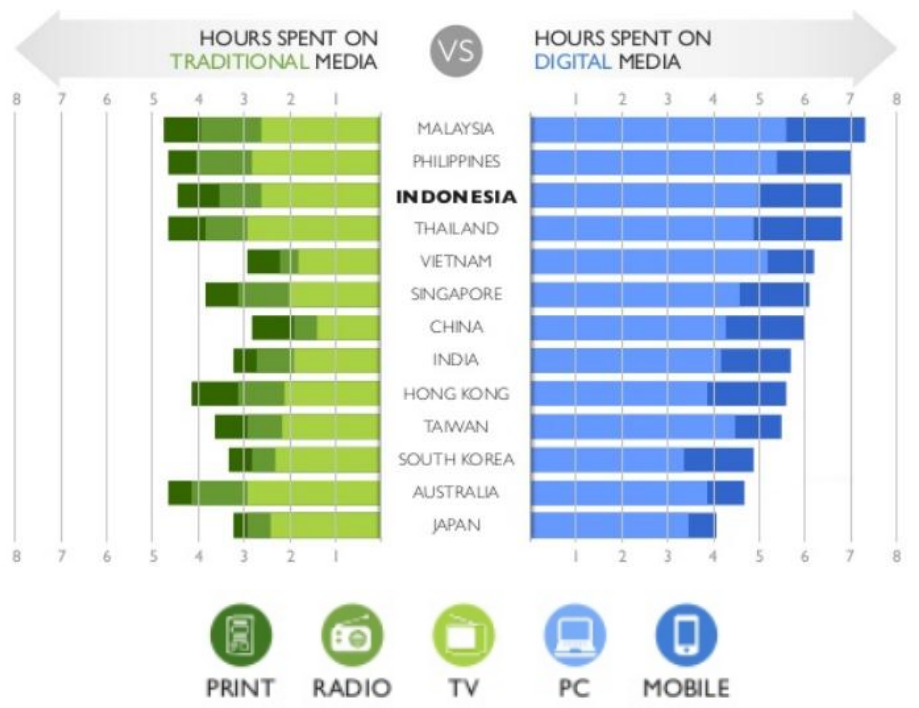

Fig. 1. Hours Spent on Traditional Media vs. Digital Media in the Asia Pacific (Atmaka, 2014)

As the number of digital media users continues to increase, advertising spending also shifts toward digital advertising. Some experts predict that digital advertising activity contributed the most in global advertising spending, which is projected to rise faster than previously expected, growing $7.2 \%$ to $\$ 550.51$ billion in 2016 (eMarketer. Video advertising in Social Media 2017: Showtime for Facebook, Snapchat, and Twitter, 2017). Moreover, Indonesia's digital advertising expenditure continues increasing with approximately two percent year-on-year growth (Fig. 2.).

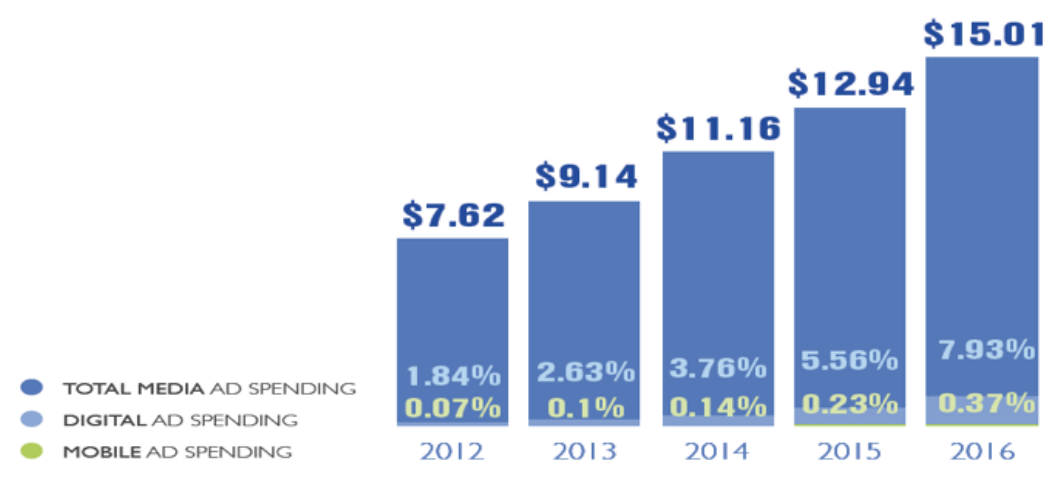

Fig. 2. Indonesia Advertising Spending Comparison (In Billions) (Atmaka, 2014)

Although Indonesia's advertising economy remains mostly reliant on traditional media advertising formats such as TV, digital advertising spending is forecasted to undergo especially high growth. Facing this change, advertisers must pay more attention to how to make digital advertising more attractive in the light of advertising effectiveness. This article highlights humorous advertising that is used on digital platforms such YouTube.

YouTube is the second largest digital platform for social networking around the globe (WeAre, 2017. Founded in 2005, it was originally intended as a platform for users to post original content they thought was interesting, funny, or worth watching for other reasons. Over the years, YouTube has become the biggest online video platform with almost 1.5 billion users worldwide. Accordingly, the website is a powerful moneymaking tool. All YouTube content can be viewed for free; however, YouTube generates the majority of its revenues through in-site advertising on its popular channels and shares a percentage of the revenue with the owners. According to Socialbakers, "Super Simple Songs-Kids Songs" has the most views around the world for the category "society" among YouTube channels (Socialbakers, 2018). It has 9.5 billion total views and 9.9 million subscribers. Based to the aforementioned facts, we can assume that most of the viewers are children.

\subsection{Assessing Children's Perceptions and Attitudes toward Humorous YouTube Advertising}

This article addresses two critical issues. First, it explores how children perceived humorous advertising on YouTube channels. Second, it investigates the advertising effectiveness using essential indicators such attitude toward the advertising and attitude toward the brand. Some cross-cultural perceptions are also explored using 
cross-tabulation. In particular, this research explores the nature of humor in advertising and collates theory regarding which factors influence audience responses that impact advertising effectiveness. In addition, for commercial practitioners, guidelines are suggested for standardizing certain elements of humor that can or cannot contribute to advertising effectiveness.

Previous research mentioned that humor in advertising depends on the content and context. In an advertising context, the content of humor includes some executional elements such as audiovisuals, the influence of music and sound effects, the spokesperson or use of spokes characters, the brand and product, and the core promotional message (Crawford \& Gregory, 2015). This article defines the theme of humor as "I think the advertisement has a hilarious character," "I think the advertisement has nice music," and "I think the advertisement has a hilarious story."

To assess the perception of humorous advertising and attitude toward YouTube advertisements, this study uses Rossiter's four-point Likert scale Rossiter (1977). ("NO_-I disagree very much," "no-I disagree," "yesI agree," and "YES-I agree very much"). The items to be explored, however, are based on (Derbaix \& Bree, 1997). This article defines the perception of humor in YouTube advertising as "I think the advertisement is hilarious," "I laughed out loud at the advertisement," and "I enjoyed watching the advertisement." To measure advertising effectiveness from the essential indicators of attitude toward the advertising, this study uses the following items: "I like this advertisement very much," "I don't like this advertisement at all," "I would really like to see this advertisement again," and "I don't really like to see this advertising again." The items to measure attitude toward the brand are "After watching the advertisement, I will certainly buy the product" and "The advertisement gives valuable information about the product." The question for the last item will be modified so the children can understand it.

\subsection{Aims of the Study}

This article explores the perceptions and the attitudes of children after they see humorous advertising on YouTube (Figure 3). We predicted that the perception of humor would have a significant impact on creating positive advertising effectiveness $\left(\mathrm{H}_{1}\right)$. Further, if it mediated by the theme of humor, the impact would be much higher $\left(\mathrm{H}_{2}\right)$. We also predicted that the theme of humor would have a positive impact on advertising effectiveness $\left(\mathrm{H}_{3}\right)$ and strengthen (moderate) the impact of the perception of humor on advertising effectiveness $\left(\mathrm{H}_{4}\right)$. Analysis of variance (ANOVA) is carried out.

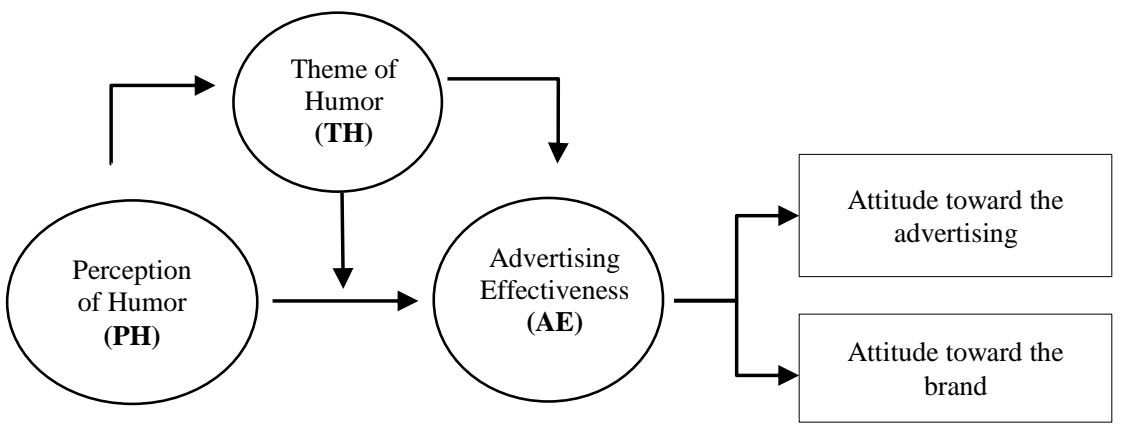

Fig. 3. Research Framework

\section{Methodology}

The study participants were 840 children (47.9\% male and $52.1 \%$ female) aged 7 to 12 years, studying in public $(41.4 \%)$ and private $(58.6 \%)$ elementary schools. They completed a 12-item questionnaire that consisted of three items on the perception of humor, three items on the perception of theme humor, and five items on advertising effectiveness. The factor structure of the scale was identified through factor analysis. Items that did not have loadings of at least .40 on any scale were dropped individually from the dataset (D'Alessio, Laghi \& Baiocco, 2009). However, this article maintains reliability to be at least .50 Cronbach's alpha (Table 1).

Table 1. Construct Validity and Reliability

\begin{tabular}{llrr}
\hline Variable & Item & Factor loadings & Cronbach's alpha \\
\hline Perception & I think the advertisement is hilarious & .659 & .665 \\
of Humor & I laughed out loud at the advertisement & .649 & .495 \\
& I enjoyed watching the advertisement & .587 & .519
\end{tabular}




\begin{tabular}{llcc}
\hline Variable & Item & Factor loadings & Cronbach's alpha \\
\hline Humor & character & .462 \\
& $\begin{array}{l}\text { I think the advertisement has nice music } \\
\text { I think the advertisement has a hilarious story }\end{array}$ & .482 & .918 \\
\hline Advertising & After watching the advertisement, I will & .516 \\
Effectivene & certainly buy the product & .548 \\
ss & $\begin{array}{l}\text { I like this advertisement very much } \\
\text { I don't like this advertisement at all (reverse } \\
\text { code) }\end{array}$ & .705 \\
I would really like to see this advertisement & .703 \\
& $\begin{array}{l}\text { again } \\
\text { I wouldn't really like to see this advertisement } \\
\text { again (reverse code) } \\
\text { The advertisement gives valuable information } \\
\text { about the product }\end{array}$ & .748 \\
\hline
\end{tabular}

In May 2018, we administered the questionnaire at six public and private elementary schools in the Greater Jakarta area. Ethic approval was obtained from the school principal beforehand. The study offered as natural a setting as possible. The children filled out the questionnaire in their classroom during school hours. The study procedure was divided into three phases. First, the children watched a modified short movie with advertising before and after, aired on a YouTube channel. We selected three 15-second advertisements for milk that is suitable to be consumed by children aged 7 to 12 (Zee, Boneeto, and Real Good). Second, the children were asked whether they consented to answering the survey questions after they saw the movie. Third, the children took the survey, which contained 12 items and some demographic questions. All the children were given the same questionnaire, and some were given assistance filling it out. The questionnaire session took about 20 to 30 minutes.

The Statistical Package for the Social Science was used to conduct simple regression and ANOVA. Post hoc analysis following ANOVA was carried out using Tukey to detect group difference $(\mathrm{p}<.05)$.

\section{Results}

Before investigating the three hypotheses, we conducted ANOVA on the children's perception of humor, perception of the theme of humor, and advertising effectiveness for the advertisements they watched (Table 3). The results of a test of homogeneity of variance showed the subjects were not homogenous; however, the data can still be analyzed (Table 2).

Table 2. Test of Homogeneity of Variance

\begin{tabular}{lrccc}
\hline & Levene Statistic & df1 & df2 & Sig. \\
\hline PH & 8.903 & 2 & 837 & .000 \\
TH & 7.138 & 2 & 836 & .001 \\
AE & 16.210 & 2 & 832 & .000 \\
\hline
\end{tabular}

Table 3. ANOVA

\begin{tabular}{llrr}
\hline & & F & Sig. \\
\hline PH & Between Groups & 82.447 & .000 \\
\hline TH & Between Groups & 31.469 & .000 \\
\hline AE & Between Groups & 2.489 & .084 \\
\hline
\end{tabular}

Table 4. Post Hoc Analysis

\begin{tabular}{|c|c|c|c|c|c|c|c|}
\hline \multicolumn{8}{|l|}{ Tukey HSD } \\
\hline \multirow[t]{2}{*}{$\begin{array}{l}\text { Dependent } \\
\text { Variable }\end{array}$} & \multirow[t]{2}{*}{ (I) Subject } & \multirow[t]{2}{*}{ (J) Subject } & \multirow{2}{*}{$\begin{array}{c}\text { Mean } \\
\text { Difference (I- } \\
\text { J) }\end{array}$} & \multirow[t]{2}{*}{$\begin{array}{l}\text { Std. } \\
\text { Error }\end{array}$} & \multirow[t]{2}{*}{ Sig. } & \multicolumn{2}{|c|}{$\begin{array}{c}\text { 95\% Confidence } \\
\text { Interval }\end{array}$} \\
\hline & & & & & & $\begin{array}{l}\text { Lower } \\
\text { Bound }\end{array}$ & $\begin{array}{l}\text { Upper } \\
\text { Bound }\end{array}$ \\
\hline \multirow[t]{6}{*}{$\mathrm{PH}$} & \multirow[t]{2}{*}{ Susu_Zee } & Boneeto & $.315^{*}$ & .071 & .000 & .15 & .48 \\
\hline & & RealGood & $-.582^{*}$ & .071 & .000 & -.75 & -.42 \\
\hline & \multirow[t]{2}{*}{ Boneeto } & Susu_Zee & $-.315^{*}$ & .071 & .000 & -.48 & -.15 \\
\hline & & RealGood & $-.898^{*}$ & .071 & .000 & -1.06 & -.73 \\
\hline & \multirow[t]{2}{*}{ RealGood } & Susu_Zee & $.582^{*}$ & .071 & .000 & .42 & .75 \\
\hline & & Boneeto & $.898^{*}$ & .071 & .000 & .73 & 1.06 \\
\hline \multirow[t]{2}{*}{ TH } & \multirow[t]{2}{*}{ Susu_Zee } & Boneeto & $.166^{*}$ & .070 & .045 & .00 & .33 \\
\hline & & RealGood & $-.374^{*}$ & .070 & .000 & -.54 & -.21 \\
\hline
\end{tabular}




\begin{tabular}{|c|c|c|c|c|c|c|c|}
\hline \multicolumn{8}{|l|}{ Tukey HSD } \\
\hline \multirow[t]{6}{*}{$\begin{array}{l}\text { Dependent } \\
\text { Variable }\end{array}$} & \multirow[t]{2}{*}{ (I) Subject } & \multirow[t]{2}{*}{ (J) Subject } & \multirow{2}{*}{$\begin{array}{c}\text { Mean } \\
\text { Difference (I- } \\
\text { J) }\end{array}$} & \multirow[t]{2}{*}{$\begin{array}{l}\text { Std. } \\
\text { Error }\end{array}$} & \multirow[t]{2}{*}{ Sig. } & \multicolumn{2}{|c|}{$\begin{array}{c}95 \% \text { Confidence } \\
\text { Interval }\end{array}$} \\
\hline & & & & & & $\begin{array}{l}\text { Lower } \\
\text { Bound }\end{array}$ & $\begin{array}{l}\text { Upper } \\
\text { Bound }\end{array}$ \\
\hline & \multirow[t]{2}{*}{ Boneeto } & Susu_Zee & $-.166^{*}$ & .070 & .045 & -.33 & .00 \\
\hline & & RealGood & $-.540^{*}$ & .070 & .000 & -.70 & -.38 \\
\hline & \multirow[t]{2}{*}{ RealGood } & Susu_Zee & $.374^{*}$ & .070 & .000 & .21 & .54 \\
\hline & & Boneeto & $.540^{*}$ & .070 & .000 & .38 & .70 \\
\hline \multirow[t]{6}{*}{$\mathrm{AE}$} & \multirow[t]{2}{*}{ Susu_Zee } & Boneeto & -.038 & .048 & .706 & -.15 & .07 \\
\hline & & RealGood & .068 & .048 & .337 & -.05 & .18 \\
\hline & \multirow[t]{2}{*}{ Boneeto } & Susu_Zee & .038 & .048 & .706 & -.07 & .15 \\
\hline & & RealGood & .106 & .048 & .071 & -.01 & .22 \\
\hline & \multirow[t]{2}{*}{ RealGood } & Susu_Zee & -.068 & .048 & .337 & -.18 & .05 \\
\hline & & Boneeto & -.106 & .048 & .071 & -.22 & .01 \\
\hline
\end{tabular}
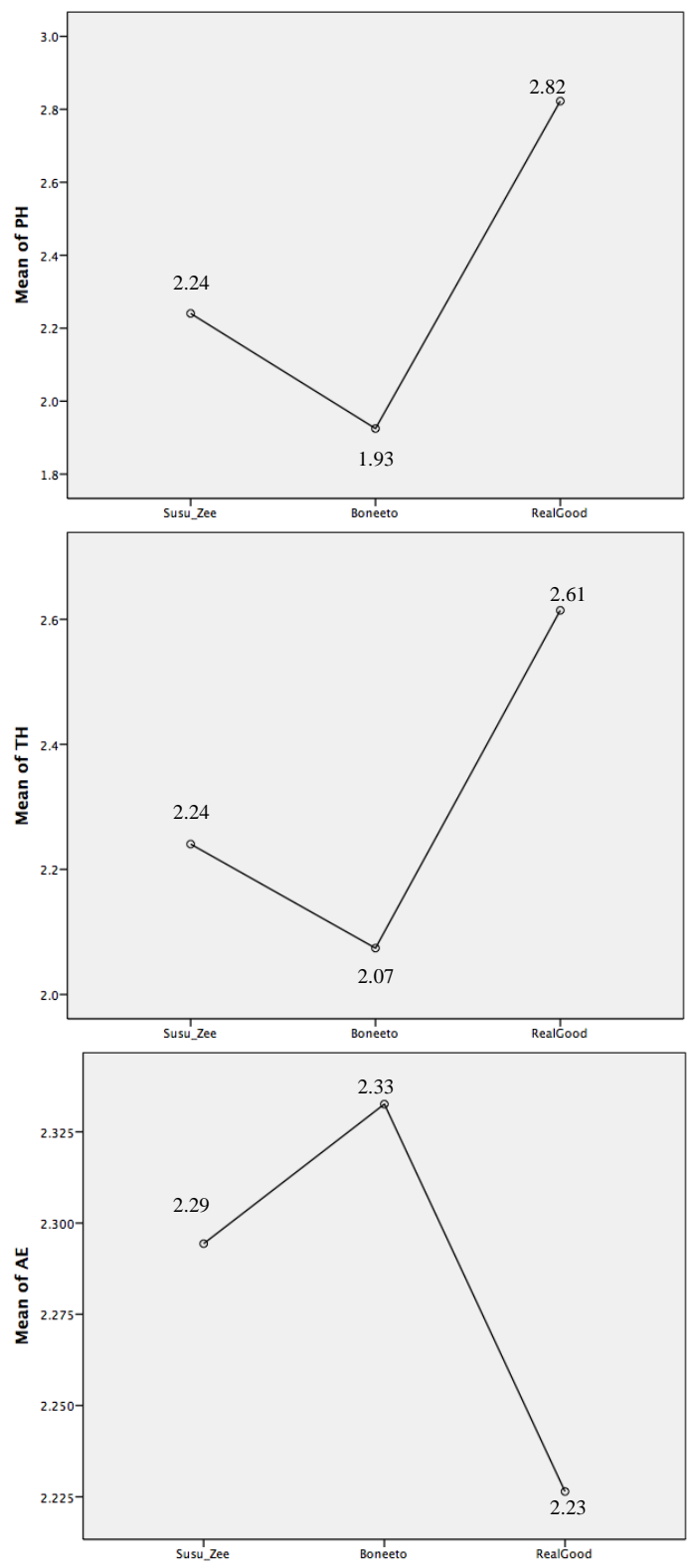

Fig. 4. Means Plot Analysis 
According to the ANOVA, there were significant group differences between the children's perceptions of humor (Sig. 000, p <.05) and the theme of humor (Sig. 000, p <.05), but not with advertising effectiveness (Sig. 084, p <.05).

Post hoc analysis and means plot following ANOVA were carried out to detect further group differences (Table 4). The post hoc analysis showed a difference in the perception of humor was significant to advertising. The Real Good advertisement had the highest value for perception of humor, and Boneeto had the lowest (Mean score: Susu Zee $=2.24$; Boneeto $=1.93$; Real Good = 2.82).

This result revealed that according to the children, the Boneeto advertisement did not give them the best time. They did not find it hilarious, laugh out loud, or enjoy watching it. This result could be devastating for the advertiser if the advertisement was indeed meant to be humorous.

Next, we looked at how children perceived the theme of humor in the Boneeto advertisement. The children seemed somewhat satisfied with the character, music, and story. Boneeto also had the lowest mean score among the advertisements (Mean Score: Susu Zee = 2.24; Boneeto = 2.07; Real Good =2.61).

However, the situation changes when the discussion is moved to advertising effectiveness. What were devastating results for the Boneeto advertisement in terms of the perception and theme of humor are significantly reversed in the findings on advertising effectiveness. Although there were only slight differences in the advertising effectiveness between the three advertisements, the Boneeto advertisement had the highest mean score (Mean Score: Susu Zee = 2.29; Boneeto = 2.33; Real Good = 2.23) (Figure 4).

Next, we investigated the first, third, and fourth hypotheses. We predicted that the perception of humor would have a significant impact on creating positive advertising effectiveness. We also predicted that the theme of humor might create a positive impact on advertising effectiveness and strengthen (moderate) the impact of the perception of humor on advertising effectiveness. In order to do this, we ran a simple regression. The results are as follows:

Table 5. Regression Analysis for Hypotheses 1, 3, and 4

\begin{tabular}{|c|c|c|c|c|c|c|}
\hline \multirow[t]{2}{*}{ Model } & \multicolumn{2}{|c|}{ Unstandardized Coefficient } & Standardized Coefficient & \multirow[t]{2}{*}{$\mathrm{t}$} & \multirow[t]{2}{*}{ Sig. } & \multirow{2}{*}{$\begin{array}{r}\text { Hypotheses } \\
\text { Support }\end{array}$} \\
\hline & $\mathrm{B}$ & Std. Error & Beta & & & \\
\hline 1 (Constant) & 4.495 & .423 & & 10.621 & .000 & \\
\hline $\mathrm{PH}$ & .651 & .189 & .326 & 3.440 & .001 & $\mathrm{H}_{1}$ Yes \\
\hline $\mathrm{TH}$ & .526 & .194 & .245 & 2.715 & .007 & $\mathrm{H}_{3}$ Yes \\
\hline $\mathrm{PH}^{*} \mathrm{TH}$ & -.041 & .072 & -.088 & -.576 & .565 & $\mathrm{H}_{4} \mathrm{No}$ \\
\hline
\end{tabular}

a. Dependent Variable: AE

According the results shown in Table 5, the perception of humor had a significant impact on creating positive advertising effectiveness ( $($.336; Sig. 001), as well as the theme of humor (ß .245; Sig. 007). However, the theme of humor did not significant moderates the impact of the perception of humor on advertising effectiveness ( $(-.088$; Sig. 565). Therefore, Hypotheses 1 and 3 are supported, while Hypotheses 4 is not.

Additional regression was conducted to investigate the second hypothesis (Table 6). Here we predicted that the perception humor that is mediated by the theme of humor would have a higher impact on advertising effectiveness. The results are as follows:

Table 6. Regression Analysis for Hypotheses 2

Coefficient a

\begin{tabular}{llrrrrr}
\hline \multirow{2}{*}{ Model } & \multicolumn{2}{c}{ Unstandardized Coefficient } & \multicolumn{2}{c}{ Standardized Coefficient } & \multirow{2}{*}{ S Sig. } \\
\cline { 2 - 5 } & \multicolumn{1}{c}{$\mathrm{B}$} & Std. Error & Beta & & \\
\hline 1 & (Constant) & .996 & .064 & & 15.498 & .000 \\
& PH & .564 & .026 & .605 & 21.971 & .000 \\
\hline
\end{tabular}

a. Dependent Variable: $\mathrm{TH}$

From the previous regression, we found the main effects of the perception of humor ( $(3336$; Sig. 001) and theme of humor ( 3.245 ; Sig. 007) on advertising effectiveness. Here, we figure the main effect of the perception of humor on the theme of humor ( $\beta .605$; Sig. 000). Therefore, the effect of the perception of humor mediated by the theme of humor toward advertising effectiveness would be $.148\left(605^{*} .245\right)$. According to the equation, the perception of humor that is mediated by the theme of humor did not have a higher impact on advertising effectiveness. Therefore, Hypothesis 2 is not data supported. 


\section{Discussion and Conclusion}

This article explored Indonesian children's views on humorous advertising on YouTube in the light of advertising effectiveness. Children were selected as representatives of demographic factors of audience response to humor in advertising, while digital advertising on YouTube was selected due to the shifting of advertising expenditures toward digital advertising, as YouTube has by far made most of its earnings this way.

The study results showed that the perception of humor had a significant impact on creating positive advertising effectiveness as well as the theme of humor. However, the theme of humor did not significantly mediate the impact of the perception of humor on advertising effectiveness. This finding may be explained by the children's response to advertising, which is based on their affective and cognitive dimensions.

In regard to affective cognition, previous literature noted that children watching commercials frequently gave responses such as "That bores me" or "Looking at it make me feel good." Even though the brand was presented very attractively the proposed benefit may often be considered of secondary importance. Cognitive cognition is the ability to understand the informative and persuasive intents of the advertising (Derbaix \& Bree, 1997). In a simple way, the affective dimension shows how children would likely perceive the humor and theme of humor that advertising shows; however it is the cognitive dimension that stimulates them to purchase or not purchase the product.

According to the aforementioned facts, the perception and theme of humor create positive advertising effectiveness because the children showed affective cognition toward the three advertisements. They not think but felt that the advertisements were hilarious. They laughed and enjoyed watching it, and that feeling influenced the advertising effectiveness. However, the study findings show that the theme of humor includes character, music, and the storytelling, of the advertising is purely independent, that it cannot used as moderating variables or mediating variable for the impact caused by the perception humor on advertising effectiveness.

In this case, this would mean the affective response of the children prevails because they are not able to develop consistent beliefs or counter-arguments. As previous literature might say both emotions and feeling play a major role in explaining how persuasion works in children. So, when an affective dimension is strongly linked to a given task, it will act as a catalyst, which will reinforce the motivation to complete the task (Wartella, 1984). Therefore, the perception and theme of humor are significant catalysts toward advertising effectiveness, but not to each other.

How children and adults react to advertising is different, because their goals in seeing advertising are totally different. Children have less reason to find any information contained in advertising, and that is what makes their preference in advertising different (Derbaix \& Bree, 1997). What children seem to look for in advertising is a state of mind where special elements can be strong enough to generate a feeling of pleasure, or in this study, a feeling of fun, laughter, enjoyable representation by the character, the music, and even the story. That is why most of advertisements aimed to children are characterized by specific features such storylines, visuals, special effects, songs, tunes, jingles, prizes, and giveaways (IOM, 2006).

The range of responses that children have toward advertising is diverse, from making purchase request to repressing their desire. Children who purchase the product simply conform to advertisers' expectations. This means the advertising was successful. Nevertheless, the children who do not make the purchase but still show some positive purchase-related behavior to the product are still worth noting. It is shown that they have desire, in a good way, for the product (Hastings, McDermott, Angus \& Stead, 2006). This means the advertising still works.

Above all, similar to the previous research, this article is shows that the affective reactions of children matter in assessing the effectiveness of advertising. Academics tend to develop operationalization that focuses on cognitive effects and theory building (Frazer, Sheehan \& Patti, 2002), whereas practitioners are interested in concrete results, such as sales volume (Synodinos, Keown \& Jacobs, 1989). This research hopefully can be fruitful for both academics and practitioners. It not only offers information on how Indonesian children perceive humorous advertising and its effectiveness, but also practitioners can use the findings to sharpen their ideas for advertising to the children.

Finally, most content of humor that have been investigates in previous advertising research are the effect of humor appeals on source credibility (Speck, 1987), source likability (Sternthal \& Craig, 1973), and product categories (Weinberger \& Campbell, 1990), but not the influence of these content factors on cross-cultural humor in advertising (i.e., (Laroche, Nepomuceno, Huang \& Richard, 2011)). This article unfortunately did not discuss this. Therefore, further research should address cultural perspectives, whether based on the advertising or on the cultural background of the audience.

Another limitation of this research is that the influence of the perception and theme of humor on advertising effectiveness was surprisingly very low $\left(\mathrm{R}^{2}=.182\right)$. No focus group discussions or in-depth interviews were held to follow up on this finding. Therefore, future research related to children use a mixed method. 


\section{Acknowledgments}

The author is indebted to the Advertising Laboratory of Communication Studies of Vocational Education Program, Universitas Indonesia, the students of communication-advertising year 2017, my fellow lecturers, and Prof. Dr. Ir. Sigit Pranowo Hadiwardoyo, DEA for the time, space, and valuable assistance during the data collection.

\section{References}

Atmaka, A. (2014). Retrieved from https://www.slideshare.net/ArdianAtmaka/indonesia-ad-spending-2013.

Crawford, H. J., \& Gregory, G. D. (2015). Humorous advertising that travels: A review and call for research. Journal of Business Research, 68(3), 569-577. doi: 10.1016/j.jbusres.2014.09.005.

D'Alessio, M., Laghi, F., \& Baiocco, R. (2009). Attitudes toward TV advertising: A measure for children. Journal of Applied Developmental Psychology, 30(4), 409-418. doi: 10.1016/j.appdev.2008.12.026.

Derbaix, C., \& Bree, J. (1997). The impact of children's affective reactions elicited by commercials on attitudes toward the advertisement and the brand. International Journal of Research in Marketing, 14(3), 207-229. doi: 10.1016/S01678116(97)00003-7.

eMarketer. Video advertising in Social Media 2017: Showtime for Facebook, Snapchat and Twitter. eMarketer Report (2017).

Frazer, C. F., Sheehan, K. B., \& Patti, C. H. (2002). Advertising strategy and effective advertising: Comparing the USA and Australia. Journal of Marketing Communications, 8(3), 149-164. doi: 10.1080/13527260210147324.

Hastings, G., McDermott, L., Angus, K., \& Stead, M. (2006). The extent, nature, and effects of food promotion to children: A review of the evidence. Stirling, UK: Institute for Social Marketing, University of Stirling and the Open University.

IOM (2006). Food marketing to children and youth: Threat or opportunity? Washington: Institute of Medicine, the National Academy Press.

Laroche, M., Nepomuceno, M. V., Huang, L., \& Richard, M.-O. (2011). What's so funny?: The use of humor in magazine advertising in the United States, China, and France. Journal of Advertising Research, 51(2), 404-416. doi: 10.2501/JAR-51-2-404-416.

Linn, S. (2004). Consuming kids. The hostile takeover of children. New York: New Press.

Rossiter, J. R. (1977). Reliability of a short test measuring children's attitudes toward TV Commercials. Journal of Consumer Research. Oxford: Oxford University Press, 3(4), 179-184. doi: 10.1086/208666.

Schor, J. B., \& Ford, M. (2007). From tastes great to cool: Children's food marketing and the rise of the symbolic. Journal of Law, Medicine and Ethics, 35(1), 10-21. doi: 10.1111/j.1748-720X.2007.00110.x. PubMed: 17341214.

Socialbakers (2018). Retrieved from http://www.socialbakers.com. $\frac{\text { Retrieved }}{\text { from }}$ https://www.socialbakers.com/statistics/youtube/channels/society/.

Speck, P. S. (1987). On humor and humor in advertising. (Volumes I and II). Dissertations, Texas Tech University, ProQuest dissertations publishing.

Sternthal, B., \& Craig, C. S. (1973). Humor in advertising. Journal of Marketing, 37(4), 12-18. doi: $10.1177 / 002224297303700403$.

Synodinos, N. E., Keown, C. F., \& Jacobs, L. W. (1989). Transnational advertising practices: A survey of leading brand advertisers in fifteen countries. Journal of Advertising Research, 29(2), 43-50.

Wartella, E. (1984). Cognitive and affective factors of TV advertising's influence on children. Western Journal of Speech Communication, 48(2), 171-183. doi: 10.1080/10570318409374152.

WeAre. (2017). Social. Digital in 2017 global overview: A collection of Internet, social media, and mobile data from around the world. hoosuite.com.

Weinberger, M. G., \& Campbell, L. (1990). The use and impact of humor in radio advertising. Journal of Advertising Research, 30(6), 44-52. 